Paweł Ćwiąkała, Karolina Matwij, Wojciech Matwij, Łukasz Miszk, Weronika Winiarska Krakow

\title{
INTEGRATION OF 2D AND TLS DATA USING GIS TO CREATE A DATABASE FOR THE PAPHOS AGORA PROJECT
}

\begin{abstract}
Excavations in the Nea Paphos Hellenistic-Roman agora have been conducted by the Chair of Classical Archaeology of the Jagiellonian University of Krakow since 2011 under the direction of Professor E. Papuci-Władyka. The main goal of the excavation is to fully uncover the Agora and to reconstruct the ways in which this public space was used. One of the methodological goals set for the research was the creation of a state-of-the-art database (work on which began in 2013) that could import and adapt data obtained from modern equipment. Of equal importance was the implementation of a 3D-format within the database (this had been under discussion for over a decade) and the enabling of GIS software data integration. Faro Focus laser scanner data was chosen to form the graphical core as it fulfilled the most important visual documentation criteria for the Paphos Agora Project database. This article presents the main premises on which the new Nea Paphos Hellenistic-Roman Agora Project database is based (on the integration of $3 D$ and $2 D$ data from 2011-2014) and the different stages of its creation, which made use of the latest methods of developing such tools for the purposes of archaeological excavations.
\end{abstract}

Keywords: 3D scanning; GIS in archaeology; $3 D$ database; agora Nea Paphos; integrating $2 D$ and $3 D$ data 


\section{Introduction}

Excavations in the Nea Paphos Hellenistic-Roman agora have been conducted by the Chair of Classical Archaeology of the Jagiellonian University of Krakow since 2011 under the direction of Professor E. PapuciWładyka. The project is funded by the National Science Center ${ }^{1}$ (PapuciWładyka and Machowski 2015; Papuci-Władyka et al. forthcoming).

As one of the most important archaeological sites in Cyprus, Nea Paphos appears on the UNESCO World Heritage List. From the late 3rd century BC onwards, it became both an administrative centre and a seat of government. The Roman Agora was discovered by K. Nicolaou (1980) opposite the odeon at the foot of Fanari hill, which is believed to have been the city's acropolis. The Agora, the square design of which measures approximately $100 \mathrm{~m}$ on each side, was first dated to the 2 nd -4 th century AD. However, researchers studying Paphos have long suggested that the square was used as an agora ever since the foundation of the city in the late 4th or early 3rd century BC (Młynarczyk 1990, 67-76; Bekker-Nielsen 2000, 201-202). This hypothesis has been proven correct by the latest findings made by the Krakow expedition, which clearly confirm that the agora existed and was used at least as early as the Late Hellenistic period (Papuci-Władyka et al. forthcoming).

Research by the Chair of Classical Archaeology of the Jagiellonian University of Krakow is intended to fully uncover the Agora and to reconstruct the ways in which this public space was used. The work conducted between 2011 and 2014 yielded outstanding results; it has now been established that the site was indeed the Agora and the dating of its foundation has been shifted back to the Late Hellenistic period at the latest. Making use of three different trenches, the excavations unearthed a complex pattern of architectural structures, which were mostly different parts of two large public buildings (probably a temple and a store house) and a tabernae by the eastern entrance to the agora. Other finds include numerous walls, floors, wells, cisterns, hydrotechnical equipment, etc. Their stratification is currently undergoing advanced study, including functional analysis, which already at an early stage indicates that the aforementioned structures went through many phases of use and were often rebuilt due to seismic activity in the region. Another factor contributing to the overall complexity of the site is its complicated stratigraphy resulting from varied backfill

\footnotetext{
1 Opus grant no. 2011/01/B/HS 3/01282 in 2011-2014 and Maestro grant no. 2014/14/A/HS 3/00283 in 2015-2019 with contributions by the Department of History of the Jagiellonian University in Krakow and private sponsors. Website: www.paphos-agora.archeo.uj.edu.pl.
} 
formation processes, varied building use and the abundance of archaeological material (Papuci-Władyka et al. forthcoming).

One of the methodological goals set for the research was the creation of a state-of-the-art database (begun in 2013) that could import and adapt data obtained from modern equipment. It was equally important to create the database in 3D format (which had been under discussion for over a decade) (Doneus and Neubauer 2005a; Doneus and Neubauer 2005b; Newhard 2015, 14-15), and to enable GIS software data integration. It was E. C. Harris (1989) who laid the foundations for this approach when he highlighted the destructive nature of archaeological research and thus the need to properly register and record explored layers/contexts by graphical means.

The first phase of work, which is presented in this article, involved the documentation of the exposed architecture of Trenches I, II and III, the creation of a 3D model and its integration with data obtained in a 'traditional' way. Due to the fact that three-dimensional documentation at the Paphos Agora site has only been introduced in stages since 2014, all of the previous documentation was based on conservative methodology, such as drawings, photographs and descriptions. With the decision to implement fully three-dimensional documentation from 2015 in the form of a GIS database based on data taken from 3D laser scanning and close range photogrammetry, there arose the need to integrate all previously collected information into digital form. This had to be completed in order to enable simultaneous processing and analysis of data obtained during the years from 2011 and 2014 and after.

\section{State-of-the-art}

The issue of the development of documentation methods and the resulting alteration in the creation of workflow for tasks on various archaeological sites is an area that has received increasing attention of late. Over at least the past dozen years, alongside the development and adaptation of laser scanning, close range photogrammetry and other related methods for creating 3D models, documentary work on archaeological sites has changed dramatically. This (r)evolution has affected not only archaeology, but also the entire area of cultural heritage protection (Campana et al. 2012; Núñez et al. 2013, 4422; Galeazzi 2015).

Laser scanning is now recognized as a tool to create $3 \mathrm{D}$ visualisations in many fields of science. In the humanities, this method was first successfully 
applied to document work in the relatively broad field of protection of cultural heritage. Creating three-dimensional models of buildings allowed for excellent inventories to be made. Moreover, the method significantly expanded the variety of possible interpretations, mainly through the taking of precise measurements and the capturing of images that registered changes in the development of building structures. Today, a combination of Terrestrial Laser Scanning (TLS) and photogrammetric methods allows a highly realistic mapping of documented architectural assumptions/principles to be constructed, which creates an impression of absolute realism in the building presented. The use of realistic three-dimensional models goes beyond purely scientific and inventory frames (Remondino et al. 2011, 283-284; Campana et al. 2012, 451-454; Papadakis et al. 2014). Their influence on modern museology, their importance in education and their role in the development of virtual reality technology cannot be overstated (Hermon 2008; Hermon and Nikodem 2008; Hermon and Kalisperis 2011).

TLS has only been used in the process of documenting archaeological information for a relatively short period of time (Doneus and Neubauer 2005a; Doneus and Neubauer 2005b). The main reason for this is the high cost of the equipment, the need to have expert knowledge of the operation of both the equipment and software and finally the lack of a clearly defined idea for its use. Since 2005, much work has been carried out in order to demonstrate the possible uses of the scanner over the course of excavations. This has mainly focused on the recording of the tops and bottoms of layers/ archaeological contexts and the creation of accurate representations of their surface appearances (Núñez et al. 2013; Galeazzi 2015). However, the most success has been achieved in the area of recording and documenting architectural remains, as well as large and complex surfaces. Although the results achieved thus far are very encouraging, certain basic difficulties must still be overcome by excavation directors wishing to use the scanner. The main problems include: the high price of the equipment, the complex workflow, the huge amount of data that needs to be developed, managed and stored, texturing problems, the problem of integrating data with information from other sources and logistical problems associated with the transportation of the device. It is also worth pointing out that despite the huge amount of information collected, the scanning results remain complementary to documentation rather than entirely replacing it (Campana and Remondino 2008, 36; Lerma et al. 2010; Dell'Unto 2014b, 61; Galeazzi 2015). The answer to these problems could lie in the development of photogrammetric methods, which are used to create three-dimensional models and to record 
the process of site exploration. Structure-from-Motion and Multi-View Stereo methods have enabled the creation of models that can now meet the accuracy requirements of archaeological documentation (Dellepiane et al. 2013; de Reu et al. 2014, 251-252). For those who conduct excavations, these methods (also known as Image-Based Modelling) have several key advantages, which have led to their ever-increasing acclaim (Campana and Remondino 2008; Lieberwirth 2008; Hermon et al. 2010, 18-19; Núñez et al. 2013; de Reu et al. 2013; Dell'Unto 2014a; de Padova 2014; de Reu et al. 2014; Galeazzi 2015; Olson and Placchetti 2015; Tsiafaki and Michailidou 2015; Miszk et al. 2016). As mentioned above, the models obtained by this method offer a sufficient level of accuracy for archaeological purposes and they also outperform laser scanning in the field of texturing (the difference is mainly due to the fact that 3D scanners are equipped with cameras of much poorer quality than average ones currently available on the market). This method of data acquisition can proceed significantly faster than the same process using a scanner, but it does require that an adequate number of photos be taken. The constantly improving/upgraded software available allows easy data management. With the development of computer hardware, it seems that it will now also be possible to check the documentation being prepared on a regular basis. This will facilitate the organisation of work on site, where the necessary halt in exploration to check whether documentation has been prepared correctly will not take as long (de Reu et al. 2014, 261; Miszk et al. 2016). However, there are no ideal solutions. Photogrammetric methods require proper exposure, which for many types of archaeological sites is a big problem. In addition, when registering large sites or complex objects, there is the issue of the huge amount of data that requires post processing, which often exceeds the capabilities of field computers (Dell'Unto 2014b, 64; Galeazzi 2015). Another problem is presented by sites which are hard to access (caves, tunnels and narrow deep trenches), where the taking of a photograph with adequate coverage is extremely difficult due to either a lack of space or an excess of it (Núñez et al. 2013, 4427; de Reu et al. 2013, 1120). For such cases, it is perhaps best to use both methods of creating 3D documentation, which in many situations may be complementary to each other (Lambers and Remondino 2008; Lerma et al. 2010, 505; Núñez et al. 2013; Koutsoudis et al. 2014; Lieberwirth et al. 2015, 116-117).

Besides the introduction of three-dimensional documentation methods, another innovation that has been of great importance in the field of data management is the introduction of GIS software that enables the integration of different kinds of spatial information in one place. GIS software has been 
used in archaeology to good effect since the 1980s, primarily in landscape research (Peterman 1992, 162) and cultural heritage protection (Apollonio et al. 2011; Campana et al. 2012, 455). Research on urban-type sites does have its own unique characteristics, but in terms of databases they represent a micro-environment that can be tested using similar tools to those used for a cultural landscape (Sharon et al. 2004, 161-162; Lambers and Remondino 2008, 31; Tsiafaki 2012, 96; Newhard 2015). Considering that all the information obtained over the course of archaeological research is of a spatial nature, the creation of a database that could collect this information is qualitatively a huge step forward. Recent years have witnessed the development of both commercial and open-source GIS software that allows the integration of $3 \mathrm{D}$ and $2 \mathrm{D}$ data. This is important not only for research currently being conducted, but it can also be used to integrate data collected previously in a traditional, digital or manual way (naturally postdigitisation). Ongoing archaeological projects at sites such as Catalhöyük and Pompeii use GIS as a basis and operate Archaeological Information Systems that collate all the data collected during excavations. In addition, these systems are able to create realistic three-dimensional models of the sites and the contexts that are explored (Núñez et al. 2013, 4421; Dell'Unto 2014b, 58; de Reu et al. 2014; Berggren et al. 2015; Forte et al. 2015, 441; Lieberwirth et al. 2015, 107). Stratigraphic data is brought together with other information regarding acquired sights, the exploration process, etc. This is essential for the facilitation of the process of interpretation by finding relationships between different sets of data and the aiding of cooperation not only between those working directly on the site, but also with those who are developing monuments or artefacts. This type of tool may also be ideally suited for the comparison of geophysical survey results with subsequent excavation results (de Reu et al. 2014, 261). The sheer volume of data collected during excavations and a growing awareness of the importance of the role that space and landscape plays in research means that the use of GIS software now seems indispensable in the execution of archaeological projects. In addition, complementary platforms for data collection, analysis and management now provide incomparably greater research, inventory and educational capabilities. To summarise, it may now be hoped that the expectations created by contemporary archaeology can finally be met.

In the case of excavations carried out on ancient Cypriot sites, 3D scanning has thus far been used during research on the hill of Agios Georgios in Nicosia (Pilides et al. 2010) and in Paphos itself during excavation of 
the theatre (Ronzino 2010). The possibility of its widespread use in analytical work on archaeological material resulted in the decision to bring all this information together in a single database. The database was created using ESRI ArcGIS software, which offers the best tools for work on threedimensional models and also enables their use in combination with different types of information. The STARC (Science and Technology in Archaeology Research Centre) programme is currently being implemented on Cyprus. One of its objectives is to develop research methodology using threedimensional modelling that best suits the particular nature of archaeological sites in Cyprus. The use of both TLS and photogrammetry techniques was tested at the Agios Georgios site and the results confirm the findings from similar research at other sites: the methods of Image-Based Modelling and laser scanning do work well in tandem and offer great opportunities, but their use does pose certain associated difficulties (Hermon et al. 2010).

\section{Case study - the Paphos Agora. Methodology and the specific nature of the site}

The first challenge posed in the creation of a modern database for the Agora site was the integration and digitisation of data obtained during research from 2011 to 2014. Most of the information obtained during these excavations was recorded on paper: inventories (monuments, distinct historic sites, contexts and structures), field logs, architectural layouts and context cards with drawings. Some information was also collected digitally: photographs, geophysical, aviation, and surveying maps. In addition, the decision was taken to create an inventory of all uncovered architectural structures, beginning with work on Trench III. The experience of conducting this work will be described below. The choice of which inventory method to use for the architectural structures (mainly walls) was dictated by the specific nature of the facilities being registered and the logistical capabilities of the expedition. Most of the exposed architectural structures included walls and partitions that were interconnected in a complicated way. In addition, they were frequently very well-preserved. This was demonstrated by the fact that over the course of exploration of the contexts lingering between the walls, the surveyed layers were often extremely thick, often exceeding $2 \mathrm{~m}$ within Trench III. In contrast, the distance between the intersecting rooms/spaces was often very small (approx. $50 \mathrm{~cm}$ ) and the courses that were preserved may have only measured up to $10 \mathrm{~mm}$ in length. Therefore, it was very long and narrow trenches that needed to be 
documented, resembling tunnels rather than classic architecture. Recording the surface of the walls with a camera whilst adhering to the principles of photogrammetry would have been very difficult or even impossible, especially when taking the bad lighting conditions in Cyprus into account (a common feature at Mediterranean sites) (Stal et al. 2014, 123). Unfortunately, even when trying to take photos at dawn or early dusk, the desired results could not always be obtained, as the fragments of architecture being recorded were too poorly lit (especially in their lower section). All of these factors combined resulted in the abandonment of photogrammetric methods in favour of laser scanning. In architectural research, the most crucial information includes data on the connection between the walls, their courses and their stages of reconstruction (Campana and Remondino 2008, 36). Thanks to collaboration with the AGH University of Science and Technology, a group of experts in laser scanning (in the mining and construction industries) were brought to the site. In this way, we were able to get around both the problem posed by the cost of purchase of the necessary equipment and that of obtaining expert support. The experts created a 3D model that served as the graphic basis for the threedimensional database created in ArcGIS. The 3D mapping of the trench served as the graphic platform on which all of the information obtained from 2011 to 2014 was integrated. The model in itself also constitutes one of the most fundamental areas of information on the database for the architecture being documented. The workflow presented above has already been successfully applied at other sites, such as Thessaloniki Toumba (Katsianis et al. 2014).

The process of presenting the stratigraphy recorded in $3 \mathrm{D}$ proved to be quite complicated on its own. The use of software described below was the result of the expedition's limited capabilities in terms of access to trial versions, open source versions and versions available from the university's (highly limited) resources. In 2015, most of these were replaced with photogrammetric software. The Image-Based Modelling method will, however, be used to its maximum capabilities when creating new documentation on the exploration of archaeological contexts (Miszk et al. 2016).

\section{Terrestrial Laser Scanning as a tool}

\section{Introduction}

Transposing the tangible world into virtual reality is becoming an increasingly important challenge, as large volumes of data are gener- 
ated during field measurement, often in a chaotic manner. In order to enhance the clarity and quality of measurement data, it is necessary to select the appropriate data acquisition and analysis method. The main factors that determine the choice of the technology best suited to the task are the area's land relief and the nature of the object of study. Recently, many 3D data acquisition methods have become available, but their applicability varies depending on site conditions (Wong et al. 2011, 3). The most important methods include photogrammetry based on image analysis, methods based on cameras that sense depth via triangulation (Hämmerle et al. 2014, 4) and classical methods based on angle and distance measurements (tacheometry and laser scanning). Owing to the nature of the site and the land relief of Paphos, laser scanning was chosen as the most appropriate method. In recent years, it has been commonly applied to all kinds of architectural surveying (González-Aguilera et al. 2009, 1). The high resolution and accuracy of the data obtained during measurement allows scanned objects to be realistically imaged and thus analysed in a precise manner. Another important advantage is that no lighting needs to be present to take measurements with a laser scanner. Lighting is only required if textures are to be recorded. Relying on personal experience and information available in topic literature regarding the application of laser scanning in the creation of 3D models for an object of study in archaeology and in related databases (Grussenmeyer et al. 2010, 2; Torres et al. 2014, 5), the project team decided to choose TLS (Terrestrial Laser Scanning).

\section{Field measurements}

The Faro Focus 3D laser scanner was used to carry out field measurements (P1. 1: 1). It is a phase scanner with a high measurement rate of 976,000 points per second. This feature allows scanned terrain to be rapidly covered with a dense point cloud, which decreases the time needed to complete measurements. The scanner is equipped with a laser rangefinder that limits the practical measurement range from $0.5 \mathrm{~m}$ to $80 \mathrm{~m}$. The ability to take measurements below the minimum or above the maximum range depends on the reflectiveness of the material covering the object of study. The wavelength of the laser beam emitted by the rangefinder belongs to the $3 \mathrm{R}$ spectrum, which poses a hazard to the eye. As a result, people operating the scanner at close range (below $5 \mathrm{~m}$ ) need to wear safety goggles. In addition, the Faro Focus 3D has an integrated 5Mpix digital camera, which can be used to take high-resolution pano-ramic photographs of the site being studied. If necessary, it is also possible 
to use panoramic pictures to overlay a point cloud with the real colours of the scanned object by adding the RGB colour code. In practice, however, it was necessary to add photogrammetry images to the point cloud from laser scanning. The high quality and accuracy of colour imaging is necessary to be able to document archaeological strata (Doneus and Neubauer 2005a, 4). In order to obtain precise images of the scanned terrain and to optimise measurement time, the mean scanning resolution was set to $7 \mathrm{~mm} / 10 \mathrm{~m}$. Due to the large number of measurement stations and short sight lines, this configuration allowed the objects (Trenches I-III of the Agora) to be comprehensively measured. Field work was carried out by two people and it took approximately ten hours to complete the measurements for one trench. In order to create an image of the entire terrain, measurements were taken from 108 stations in total. However, an analysis of the results seen on the orthophotomaps below (Pls. 1: 2 and 2,3) could lead to the conclusion that certain areas were not recorded during measurement. This was caused by the existence of very steep and deep voids (e.g. a well in Trench II) and by the screening of some elements by other elements, a situation hard to eliminate when the object of study has complex geometry. Measurements taken with the laser scanner were then inputted into the excavation's coordinate system. In order to achieve this, a Total Station that was used every day on site was employed. The connection was created with the use of check board targets that were distributed and surveyed by means of the laser scanner and a reflectorless Total Station. The targets also served as characteristic points used to combine scans recorded from different stations. This registration method allowed the scans to be pre-combined. In order to increase the accuracy of the measurement results, a Cloud-toCloud registration algorithm was used that was based on a multi-iterative analysis of the shape and location of the point cloud. The overall accuracy of the scans obtained from the abovementioned methods ranged from between 4 to $6 \mathrm{~mm}$ depending on the trench being scanned. On the basis of the positional errors of the reference targets and the errors associated with determining the position of single scan points, the total error of the model can be estimated at $10 \mathrm{~mm}$. This is the level of accuracy recommended for the documentation of archaeological sites (Doneus and Neubauer 2005b, 5). Office work to combine the point clouds into one coordinate system took 4 to 6 hours per trench.

\section{Data analysis}

A combined point cloud that presents a 3D model of a measured object is a wonderful source of data for a number of analyses, the simplest of 
which is the measurement of distance between selected elements. Spatial and reduced horizontal and vertical measurements can also be performed. During the Agora excavations, TLS data was used on various occasions to verify the relative position of structural elements of the buildings being unearthed in order to plan work associated with the exploration of further contexts. Basic point cloud operations are enhanced if simple geometric structures can be fitted into them, such as plains or spheres, although more complex shapes can also be modelled with their use. An important deliverable obtained as a derivative of a point cloud is a high-resolution orthophotomap of the scanned space. It must be noted that single object orthophotoplans, such as the representation of a wall or a trench fragment, can also be obtained. An obvious flaw in these images is the poor quality of the photographic material acquired when using the scanner. Many scanned areas are either underexposed or overexposed. Plates 4 and 5: 1 show point clouds with overlaid colours that come from a photo camera integrated into the scanner. Taking extra photographs with an external camera with better optical parameters and shading or lighting a trench is one possible solution. It is worth pointing out that a completed orthophotomap, though slightly inferior in quality, can serve as an excellent base for the sketching and planning of further excavation work. A complete point cloud permits the easy generation of cross-sections, which can be executed at any horizontal or vertical angle and at any height (Pl. 5: 2). Point cloud data can also be used to draw contours of architectural details by simply slicing the point cloud. Slices can be generated automatically, which can significantly speed up work of this kind under certain conditions. Terrestrial scanning can also be used in order to record subsequent stages in the unearthing of contexts. This is presented in Plates 6 and 7: 1 in the form of a triangulated irregular network (TIN) for the three excavation stages and in the form of cross-sections. This functionality permits the graphical extraction of the contexts explored in their true shape and provides insight into the whole exploration process (Doneus and Neubauer 2005b, 3; Lieberwirth et al. 2015, 105). Another interesting, albeit rarely applied, feature of laser scanning is its ability to measure the impact of weather and time on the condition of historic buildings. The comparison of models of studied objects from different measurement periods could enable the generation of deviation maps indicating differences in appearance and shape. It would thus be possible to determine the rate of change and to identify the elements which are most at risk of deformation. This type of approach could play an especially important role in regions that are seismically active, such as Cyprus (Ambraseys 2009, x). 


\section{D database for the Paphos Agora Project}

\section{Introduction}

In the article Discourse on the use of a $3 D$ model as a record of excavation, G. J. Avern $(2013,9)$ expressed his opinion on the future of excavation records, writing that they will consist of two parts joined together; the first will be a precise 3D model of a site with the second being a database that includes traditional documentation data, such as descriptions, pictures, drawings, etc. This record taking method, which is based on the use of modern technology, has been adopted at the Nea Paphos agora site in Cyprus, where an Archaeological and Archaeometric Information System (AAIS) is currently being created. It is made up of a few crucial components (including traditional documentation) that together form a computer database that works as the fundamental tool for the processing and analysis of archaeological material.

\section{Creation of the database}

Esri ArcGIS ArcInfo software was chosen as the basic set of computer tools to be used for the GIS environment at the Agora site. This choice was not random. The decisive advantage of using this software was its ability to work in 3D (ArcScene programme with the ArcGIS 3D Analyst extension), which enables both the development of a database and offers a way to create a visualisation and partial reconstruction of the site being explored. The ArcGIS package offers many possibilities, of which the following are particularly worthy of mention: storage of collected information, cataloguing according to pre-defined parameters and the creation and editing of various data types. Another important advantage of this software is its ability to build multiple visualisations by comparing selected data, as well as conducting analyses using an impressive number of built-in applications. The first stage of creating AAIS for the Agora site involved gathering all the data obtained thus far and transferring it into the GIS environment. This data can be divided into two categories (Pl. 7: 2):

Vector data: 1. Numerical Terrain Model (point layer); 2. 3D Model of Trench 3 (multipatch layer); 3. Table of Separated Finds (point layer); 4. Layers drawn in 3D (multipatch layer).

Raster data: 1. photographs; 2. orthophotoplans; 3. architectonic sketches; 4. orthophotomaps.

One of the most basic graphical elements of the project database is a $3 \mathrm{D}$ model of Trench III (Pl. 8: 1). This was developed on the basis of a colour 
point cloud, which was obtained during Terrestrial Laser Scanning in 2014. The use of this technology significantly decreased the time required for documentation and produced much better results than a standard Total Station would have (Doneus and Neubauer 2005b, 226). The raw material obtained was processed through a number of programs in the following order: cleaning up of the point cloud $\rightarrow$ creating meshes $\rightarrow$ combining meshes $\rightarrow$ modelling $\rightarrow$ texturing. The completed model was saved in the *.3ds (3D Studio Max) format and imported as a multipatch layer into the GIS environment with the use of ArcToolbox. In addition, the Cloud Compare freeware allowed the division of the mesh into smaller elements (structures identified during excavations) and the reloading of the layer with an extended attribute table containing more multipatch items, which enabled more detailed analysis to be conducted. In this case, it was crucial to isolate each piece of information on a separate layer, as it not only contributed to more effective browsing of the database, but also made the database clearer and more readable.

Another element of the GIS database is the 3D presentation of stratigraphy (P1. 8: 2). Archaeological excavations are a destructive process, as each layer can be explored only once with no reversal possible. Therefore, the importance of precise documentation cannot be overestimated. Thus far, a few stratigraphy presentation solutions based on the usage of contemporary equipment and software have been proposed (e.g. Doneus and Neubauer 2005b; Lieberwirth 2008; Forte 2014). At the agora site, MicroStation V8i software was used. This program is a CAD tool, which in archaeology is mainly applied to digitisation (Neamtu et al. 2011, 79; Lieberwirth et al. $2015,105)$. During fieldwork, points located in the roof corners of each layer were measured with a Total Station. X, y, and z coordinates obtained in this way were imported into the program, where they served as the basis for the drawing of planes, which were then combined to form 3D models of individual contexts on separate layers. Data prepared in this way was divided into separate files in FME Desktop 2015.1., converted into the *.shp format and transferred into the GIS environment as multipatch objects (P1. 8: 3). A similar method has been adopted at the Thessaloniki Toumba site (Katsianis et al. 2014).

During fieldwork, the team measures each separate find with a Total Station in order to assign its unique $\mathrm{x}, \mathrm{y}$ and $\mathrm{z}$ coordinates. Next, this information and a detailed description of the find are uploaded into the database, which is developed in Microsoft Excel, but can easily be imported into the GIS environment. This is achieved by saving a given Excel sheet as a *.csv or *.xlsx file and opening it in ArcGIS, which displays each 
record as a separate point element, represented by a pre-defined symbol. The database can be modified with both ArcGIS and Microsoft Excel.

In the Paphos Agora Project, non-destructive archaeological methods are also employed. The resulting abundance of mainly digital data is a rich source of information on the site. In the GIS environment, this data is categorised as raster layers, which present photographs, plans and maps. This sort of information can be directly added to the created database, although without georeference it will not be displayed in the proper location. As a result, each image undergoes a coordinate assignment process (known as calibration, georeference or georectification) before being imported into ArcScene.

All of the aforementioned elements are gathered together and uploaded into a single GIS database in ArcScene. If desired, each layer can be edited, modified in terms of its attributes and geometry or complemented with attachments, depending on specific requirements or software functionalities. It should also be pointed out that all the traditional records are scanned and added to their respective layers as attachments. ArcScene has a range of functionalities, which both speed up and facilitate material analysis. Information gathered in one location can be displayed in many ways as configured by the user. Question-and-answer browsing allows the user to easily access data on all layers and combine and divide them with the available ArcToolbox options. Research results can also be shared as digital or printable maps or even as Internet apps. Another great advantage of the GIS database is that it is an open system, which means that new data can always be uploaded into it and that the software is continuously updated. It is therefore to be expected that once new documentation methods have been developed, we will be able to implement them into the existing database (Pl. 8: 4).

The graphical component of the database will be continuously expanded to encompass the whole of the Agora, as well as other sites that are studied in detail. A 3D model of Trenches I and II is currently being created with the use of laser scanning and tacheometric measurements of the sills and roofs of the recorded contexts. Thanks to the greater possibilities afforded by the new AgiSoft Structure from Motion photo-based 3D modelling software and the greater availability of scanners, the records of all the contexts explored will be imaged much more accurately than before.

The newly-created GIS database for the Agora allows all the information obtained on it to be gathered in one environment, a feat that was made possible by the application of state-of-the-art technology and tools. All of the aforementioned operations have led to the formation of a virtual 
archaeological site available to all users via a computer screen. This sort of documentation not only allows the emerging image of the past to be accurately preserved, but can also be made accessible to a wider audience in an interesting, appealing and friendly manner.

\section{Summary}

Laser scanning and GIS are becoming increasingly important tools in archaeological work andthis article has presented the process of creating 3D documentation and implementing it into a GIS environment. In conclusion, it should be emphasised that laser scanning is not only a perfect tool for the recording of unearthed objects and architecture, but also for the accurate registration of every step of exploration. Its main advantages include short data recording and pre-processing time, the objective quality of information that is obtained and the ability to execute precise orthophotoplans or crosssections in any desired configuration. Texture application remains problematic for the time being, but it will be resolved by combining photogrammetry images with scanning data.

A great improvement in data-processing results can be observed when implementing all of the information obtained into a single database, which in this particular case used GIS software. It allows information to be easily accessed, handled and filtered as desired. One difficulty that is encountered, however, is the implementation of scanned data into a 3D model that keeps it accessible at its highest resolution possible. At present, this appears to be a hardware-related obstacle. It is also hard to overestimate the universal nature of the system discussed in this article. Geographic Information Systems allow users to work in a universal environment, which all interested parties can access (without the need to learn new software) and other archaeological expeditions working at the same site can also contribute to it at a later date (Sharon et al. 2004, 161-162).

Furthermore, it should be emphasised that with the development of photogrammetry techniques, laser scanning will increasingly become a purely ancillary method. However, its application will still have a significant impact at sites where the Image-Based Modelling method cannot be used.

Considering the problem of modern documentation when developing a site, it should be noted that laser scanning has allowed significant progress in the fields of accessibility, accuracy and quality. One simply cannot overestimate how useful it is to be able to analyse any given thread/ course of a wall, to make accurate measurements, and, last but not least, to 
search for relationships between the 3D and 2D data collected in the GIS (Stal et al. 2014, 123-125). The experience of numerous case studies shows that Ian Hodder (1999, 180-181) was right when he predicted the huge impact that digitisation would have on archaeology.

\section{References}

Ambraseys N. 2009. Earthquakes in the Mediterranean and Middle East. New York.

Apollonio F. I., Benedetti B., Gaiani M. and Baldissini S. 2011. Construction, management and visualization of 3D models of large archaeological and architectural sites for e-heritage GIS systems. In K. Pavelka (ed.), 23rd International CIPA Symposium Proceedings, Prague, 12-16 September 2011, B.2.97-B.2.104. Prague.

Avern G. J. 2013. Discourse on the use of a 3D model as a record of excavation. In. F. Contreras, M. Farjas and F. J. Melero (eds.), Fusion of Cultures. Proceedings of the 38th Annual Conference on Computer Applications and Quantitative Methods in Archaeology, Granada, Spain, April 2010, 9-13. Oxford.

Bekker-Nielsen T. 2000. The foundation of Nea Paphos. In S. Isager and I. Nielsen, Proceedings of the Danish Institute at Athens 3, 195-207. Aarhus.

Berggren Å., Dell'Unto N., Forte M., Haddow S., Hodder I., Issavi J., Lercari N., Mazzucato C., Mickel A. and Taylor J. S. 2015. Revisiting reflexive archaeology at Çatalhöyük: integrating digital and 3D technologies at the trowel's edge. Antiquity 89, 433-448. 
Campana S. and Remondino F. 2008. Fast and detailed digital documentation of archaeological excavations and heritage artifacts. In A. Posluschny et al. (eds.), 36-42.

Campana S., Bianchi G., Fichera G. A., Lai L. and Sordini M. 2012. $3 \mathrm{D}$ recording and total archaeology: from landscapes to historical buildings. International Journal of Heritage in the Digital Era 1/3, 444-460.

Dellepiane M., Dell'Unto N., Callieri M., Lindgren S. and Scopigno R. 2013. Archeological excavation monitoring using dense stereo marching techniques. Journal of Cultural Heritage 14/2, 201-210.

Dell'Unto N. 2014a. The use of 3D models for intra-site investigation in archaeology. In F. Remondino and S. Campana (eds.), 3D Recording and Modeling in Archaeology and Cultural Heritage. Theory and Best Practices, 151-158. (BAR-IS 2598). Oxford.

Dell'Unto N. 2014b. 3D models and archaeological investigation. In H. Isto (ed.), Perspectives to Archaeological Information in the Digital Society, 55-71. Uppsala.

Doneus M. and Neubauer W. 2005a. 3D Laser scanner on archaeological excavations. In S. Dequal (ed.), International Cooperation to Save the World's Heritage. Proceedings of the 20th International Symposium CIPA, Torino, 26 September-1 October 2005, 226-231. Turin.

Doneus M. and Neubauer W. 2005b. Laser scanners for 3D documentation of stratigraphic excavations. In M. Baltsavias, A. Gruen, L. van Gool and M. Pateraki (eds.), Recording, Modelling and Visualization of Cultural Heritage, Ascona, 22-27 May 2005, 193-204. London, Leiden, New York, Philadelphia, Singapore.

Forte M. 2014. 3D archaeology: new perspectives and challenges the example of Çatalhöyük. Journal of Eastern Mediterranean Archaeology and Heritage Studies 2/1, 1-29.

Forte M., Dell'Unto N., Jonsson K. and Lercari N. 2015. Interpretation process at Çatalhöyük using 3D. In I. Hodder and A. Marciniak (eds.), Assembling Çatalhöyük, 43-58. (Themes in Contemporary Archaeology 1). Leeds. Retrieved from http://lup.lub.lu.se/record/5276566 (status as of Dec. 31st, 2015).

Galeazzi F. 2015 (in press). Towards the definition of best 3D practices in archaeology: assessing 3D documentation techniques for intra-site data recording. Journal of Cultural Heritage.

González-Aguilera D., Muñoz-Nieto A., Gómez-Lahoz J., HerreroPascual J. and Gutierrez-Alonso G. 2009. 3D digital surveying and 
modelling of cave geometry: application to Palaeolithic rock art. Sensors 9, 1108-1127.

Grussenmeyer P., Landes T., Alby E. and Carozza L. 2010. High resolution $3 \mathrm{D}$ recording and modelling of the bronze age cave "Les Fraux" in Périgord (France). In J. P. Mills, D. M. Barber, P. E. Miller and I. Newton (eds.), Proceedings of the ISPRS Commission 5 Mid-Term Symposium 'Close Range Image Measurement Techniques', Newcastle upon Tyne, 21-24 June 2010, 262-267. (International Archives of Photogrammetry, Remote Sensing and Spatial Information Sciences 38/5). Newcastle upon Tyne.

Hämmerle M., Höfle B., Fuchs J., Schröder-Ritzrau A., Vollweiler N. and Frank N. 2014. Comparison of Kinect and Terrestrial LiDAR Capturing Natural Karst Cave 3-D objects. IEEE Geoscience and Remote Sensing Letters 11/11, 1896-1900.

Harris E. C. 1989. Principles of Archaeological Stratigraphy. London.

Hermon S. 2008. 3D modelling and virtual reality for the archaeological research and museum communication of cultural heritage. In I. Oberländer-Târnoveanu (ed.), Museum and the Internet: Presenting Cultural Heritage Resources On-line. Selected Papers from the International Summer Course in Buşteni, Romania, 20-26 September 2004, 57-73. Budapest.

Hermon S. and Nikodem J. 2008. 3D modelling as scientific research tool. In A. Posluschny et al. (eds.), 140-146.

Hermon S., Pilides D., Amico N., D'Andrea A., Iannone G. and Chamberlain M. 2010. Arc 3D and 3D Laser-Scanning. A comparison of two alternate technologies for 3D data acquisition. In. J. F. Melero et al. (eds.), 55-58.

Hermon S. and Kalisperis L. 2011. Between the real and the virtual: 3D visualization in archaeological research - expectations and prospects. Virtual Archaeology Review 2/4, 59-63.

Hodder I. 1999. The Archaeological Process: an Introduction. Oxford.

Katsianis M., Tsipidis S. and Kalisperakis I. 2014. Archaeological research in the digital age. In C. Papadopoulos et al. (eds.), 46-54.

Koutsoudis A., Vdima B., Ioannakis G., Arnaoutoglou F., Pavlidis G. and Chamzas C. 2014. Multi-image $3 \mathrm{D}$ reconstruction data evaluation. Journal of Cultural Heritage 15/1, 73-79.

Lambers K. and Remondino F. 2008. Optical 3D measurement techniques in archaeology: recent developments and applications. In A. Posluschny et al. (eds.), 27-35. 
Lerma J. L., Navarro S., Cabrelles M. and Villaverde V. 2010. Terrestrial laser scanning and close range photogrammetry for $3 \mathrm{D}$ archaeological documentation: the Upper Palaeolithic Cave of Parpallo' as a case study. JAS 37, 499-507.

Lieberwirth U. 2008. 3D GIS voxel-based model building in archaeology. In A. Posluschny et al. (eds.), 1-8.

Lieberwirth U., Fritsch B., Metz M., Neteler M. and Kühnle K. 2015. Applying low budget equipment and open source software for high resolution documentation of archaeological stratigraphy and features. In A. Traviglia (ed.), Across Space and Time. Papers from the 41st Annual Conference of Computer Applications and Quantitative Methods in Archaeology (CAA), Perth, 25-28 March 2013, 104-119. Amsterdam.

Melero J. F., Cano P. and Revelles J. (eds.) 2010. Fusion of Culture. Abstracts of the 38 Conference on Computer Applications and Quantitative Methods in Archaeology, Granada, Spain, 6-9 April 2010. Granada.

Miszk Ł., Ostrowski W. and Hanus K. 2016. Close range and UAV-based photogrammetry in the Paphos Agora Project research and documentation process. In. E. Papuci-Władyka and A. Dobosz (eds.), In the Heart of the Ancient City. Five Years of Krakow Archaeologists' Research at the Paphos Agora on Cyprus (2011-2015). International Symposium and Exhibition of Photographs by Robert Słaboński, Krakow, 21-22 January 2016, 22-26, Krakow.

Młynarczyk J. 1990. Nea Paphos 3. Nea Paphos in the Hellenistic Period. Warsaw.

Neamtu C., Popescu D. and Mateescu R. 2011. From classical to 3D archaeology. Annales d'Université Valahia Targoviste. Section d'Archéologie et d'Histoire 13/1, 79-88.

Newhard J. 2015. 3D imaging in Mediterranean archaeology: what are we doing, anyway? In B. R. Olson and W. R. Caraher (eds.), 9-16.

Nicolaou K. 1980. Archaeological news from Cyprus 1977-1978. AJA 84, 70-71.

Núñez A., Buill F. and Edo M. 2013. 3D model of the Can Sadurní cave. $J A S 40 / 12,4420-4428$.

Olson B. R. and Plachetti R. A. 2015. A discussion of the analytical benefits of image based modelling in archaeology. In B. R. Olson and W. R. Caraher (eds.), 17-26. 
Olson B. R. and Caraher W. R. (eds.) 2015. 3 D Imaging in Mediterranean Archaeology. North Dakota.

Padova M. D. de 2014. Fieldwork 3D interpretation: integrating established methods and emerging technologies in a medieval context. In W. Börner and S. Uhlir (eds.), CHNT 18. Proceedings of the International Conference on Cultural Heritage and New Technologies. Vienna. Retrieved from http://www.chnt.at/wp-content/uploads/DePadova_ 2014.pdf (status as of Dec. 31st, 2015).

Papadakis G., Kourouppis S., Katsianis M. and Alexopoulos Y. 2014. Archaeological research in the digital age. In C. Papadopoulos et al. (eds.), 197-205.

Papadopoulos C., Paliou E., Chrysanthi A., Kotoula E. and Sarris A. (eds.) 2014. Archaeological Research in the Digital Age. Proceedings of the 1st Conference on Computer Applications and Quantitative Methods in Archaeology Greek Chapter (CAA-GR), Rethymno, Crete, 6-8 March 2014. Rethymno.

Papuci-Wladyka E. and Machowski W. 2015 (in press). PAPHOS AGORA PROJECT. Preliminary results of the 2011-2012 seasons of the Jagiellonian University (Krakow, Poland) excavations. In C. Balandier (ed.), Nea Paphos, Fondation et développement urbain d'uneville chypriote de l'antiquité à nos jours. Études archéologiques, historiques et patrimoniales. Colloque international, Université d'Avignon 2012. Bordeaux.

Papuci-Władyka E., Machowski W. and Miszk $\mathbf{L}$. in collaboration with M. Biborski, J. Bodzek, A. Dobosz, M. Droste, M. Kajzer, E. Marzec, K. Nocoń, K. Rosińska-Balik and M. Waclawik forthcoming. Paphos Agora Project (PAP) 2011-2014: first preliminary report on excavations by Jagiellonian University in Krakow, Poland (with Appendix 1: Preliminary observations on animal remains from Krakow University excavations at the Agora of Nea Paphos by P. Croft). $R D A C$ (New Series 2, 2015).

Peterman G. L. 1992. Geographic information system: archaeology's latest tool. The Biblical Archaeologist 55/3, 162-167.

Pilides D., Hermon S., Amico N., Chamberlain M., D'Andrea A., Iannone G. and Ronzino P. 2010. The Hill of Agios Georgios, Nicosia: 3D analysis of an ongoing archaeological excavation. In J. F. Melero et al. (eds.), 325-328.

Posluschny A., Lambers K. and Herzog I. (eds.) 2008. Layers of Perception. Proceedings of the 35th International Conference on Computer Applications and Quantitative Methods in Archaeology (CAA), Berlin, 
Germany, 2-6 April 2007. (Kolloquien zur Vor- und Frühgeschichte 10). Bonn.

Remondino F., Rizzi A., Jimenez Fernandez-Palacios B., Agugiaro G., Baratti G. and Amicis R. de 2011. The Etruscan in 3D: from space to underground. Geoinformatics FCE CTU Journal 6, 283-290.

Reu J. de, Plets G., Verhoeven G., Smedt P. de, Bats M., Cherretté B., Maeyer W. de, Deconynck J., Herremans D., Laloo P., Meirvenne M. van and Clercq W. de 2013. Towards a three-dimensional costeffective registration of archaeological heritage. JAS 40, 1108-1121.

Reu J. de, Smedt P. de, Herremans D., Meirvenne M. van, Laloo P. and Clercq W. de 2014. On introducing an image-based 3D reconstruction method in archaeological excavation practice. JAS 41, 251-262.

Ronzino P. 2010. Innovative techniques for $3 \mathrm{~d}$ digital survey of the Paphos Theatre. In 24 FIG Congress 2010. Facing the Challenges - Building the Capacity, Sydney, Australia, 11-16 April 2010, 1-9. Retrieved from htpp://www.cng.it/CNG_NEW_SITE/internazionale/ fig/DOCUMENTI/Relazione\%20Geom.\%20Ronzino,\%20XXIV\%20 FIG\%20International $\% 20$ Congress, $\% 20 \%$ Sydney $\% 2011-16 \% 20$ aprile $\% 202010 \% 20 \% 20$ Commissioni\%20FIG\%20V\%20e\%2VI_145 $187963 \mathrm{ccffcc} . p d f$ (status as of Dec. 31st, 2015).

Sharon I., Dagan Y. and Tzionit G. 2004. The [awful?] truth about GIS and archaeology. In M. Iacovou (ed.), Archaeological Field Survey in Cyprus: Past History, Future Potentials, 151-162. (British School at Athens Studies 11). Athens.

Stal C., Liefferinge K. van, Reu J. de, Docter R., Dierkens G., Maeyer P. de, Mortier S., Nuttens T., Pieters T., Eijnde F. van den, Put W. van de and Wulf $A$. de 2014. Integrating geomatics in archaeological research at the site of Thorikos (Greece). JAS 45, 112125.

Torres J. A., Hernandez-Lopez D., Gonzalez-Aguilera D. and Hidalgo M. A. M. 2014. A hybrid measurement approach for archaeological site modelling and monitoring: the case study of Mas D'Is, Penaguila. JAS 50, 475-483.

Tsiafaki D. 2012. The contribution of new technologies in archaeology: goals and issues. In N. Zacharias (ed.), Proceedings of the 2nd Symposium - Archaeological Research and New Technologies ARCH RNT, Kalamata, 21-23 October 2010, 2012, 93-98. Kalamata.

Tsiafaki D. and Michailidou N. 2015. Benefits and problems through the application of 3D technologies in archaeology: recording, 
visualisation, representation and reconstruction. Scientific Culture 1/3, 37-45.

Wong U., Morris A., Lea C., Lee J., Whittaker Ch., Garney B. and Whittaker R. 2011. Comparative evaluation of range sensing technologies for underground void modelling. In N. M. Amato (ed.), IEEE/RSJ International Conference on Intelligent Robots and Systems, San Francisco, 25-30 September 2011, 3816-3823. Retrieved from http://ieeexplore.ieee.org/xpl/mostRecentIssuejsp?punumber=6034548, (status as of Dec. 31st, 2015).

Paweł Ćwiąkała

Faculty of Mining Surveing and Environmental Engineering AGH University of Science and Technology pawelcwi@gmail.com

Karolina Matwij Faculty of Mining Surveing and Environmental Engineering AGH University of Science and Technology kmatwij@agh.edu.pl

Wojciech Matwij

Faculty of Mining Surveing and Environmental Engineering AGH University of Science and Technology matwij@agh.edu.pl

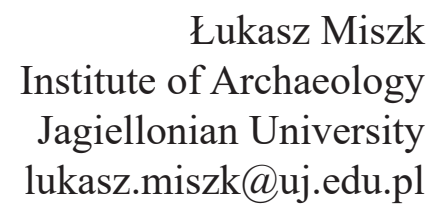

Weronika Winiarska

Faculty of Environmental Engineering and Land Surveying University of Agriculture weronika22.01@gmail.com 


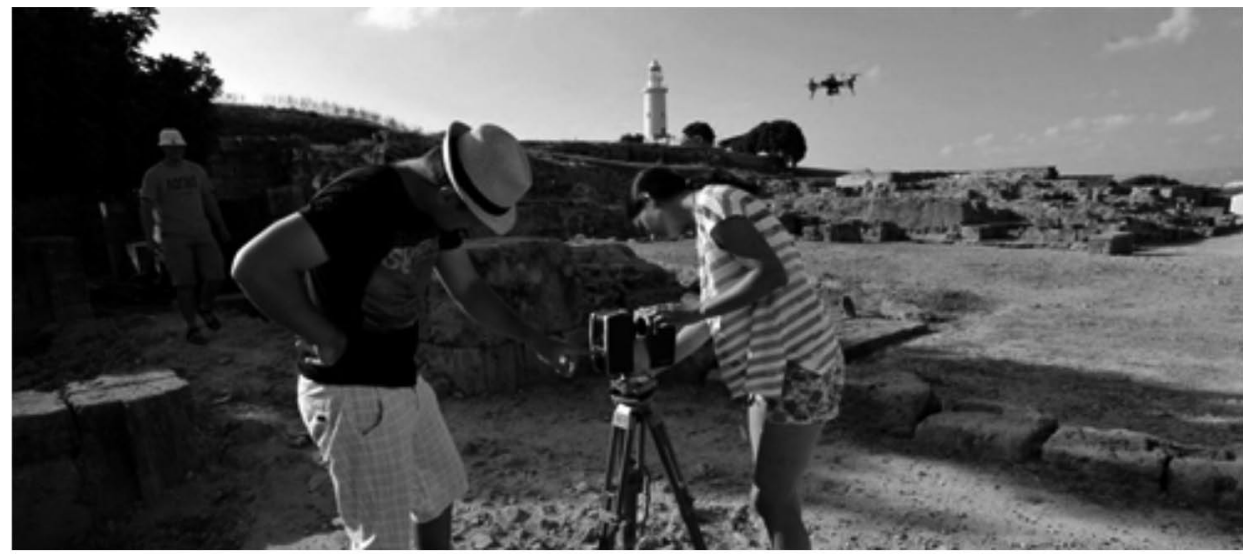

1

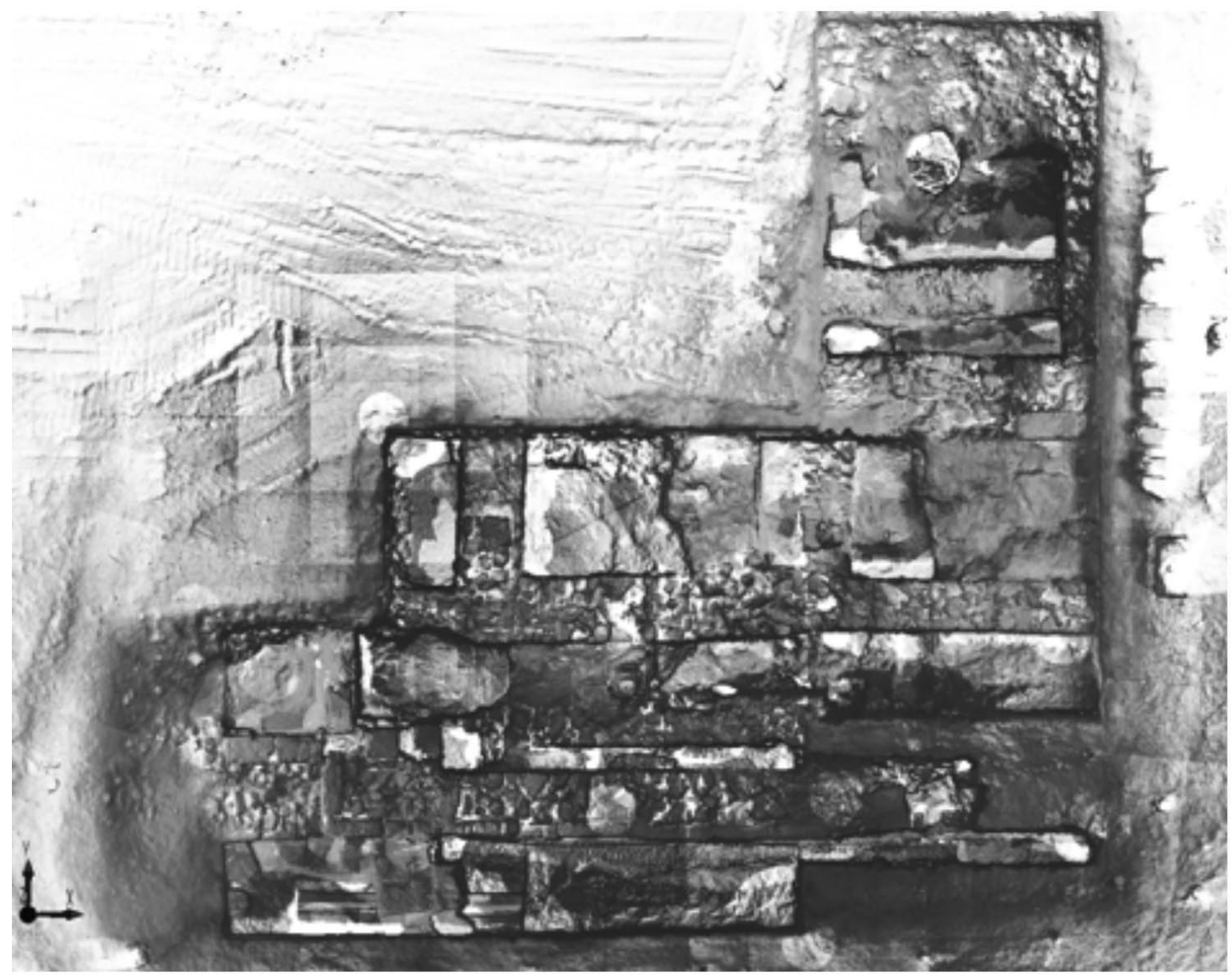

Pl. 1. 1 -3D Scanner Faro Focus during fieldwork. Photo by R. Słaboński; 2 - Orthophotomap of Trench I from scanning measurements. Drawn by P. Ćwiąkała, K. Matwij, W. Matwij 


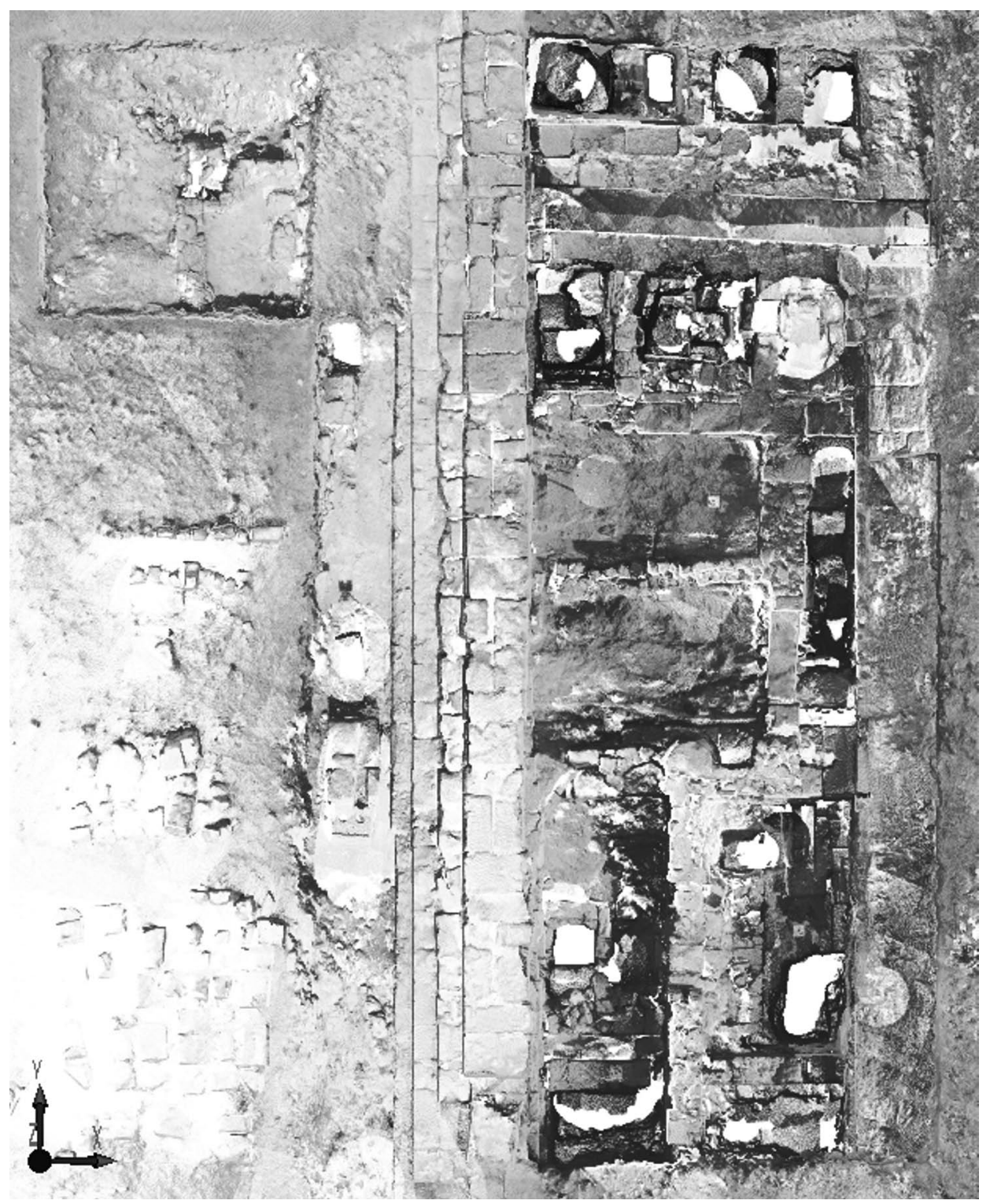

P1. 2. Orthophotomap of Trench II from scanning measurements. Drawn by P. Ćwiąkała, K. Matwij, W. Matwij 


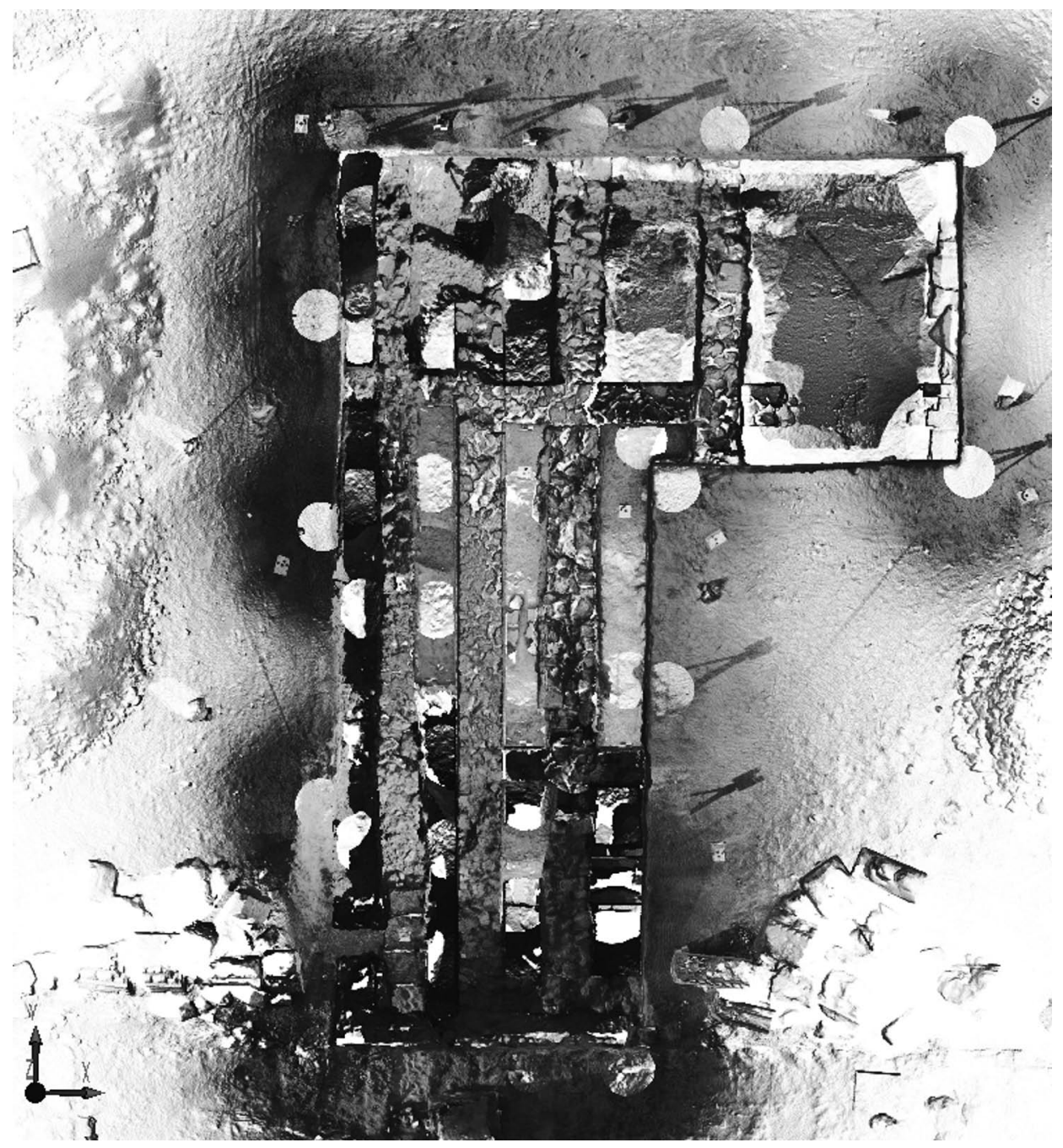

P1. 3. Orthophotomap of Trench III from scanning measurements. Drawn by P. Ćwiąkała, K. Matwij, W. Matwij 

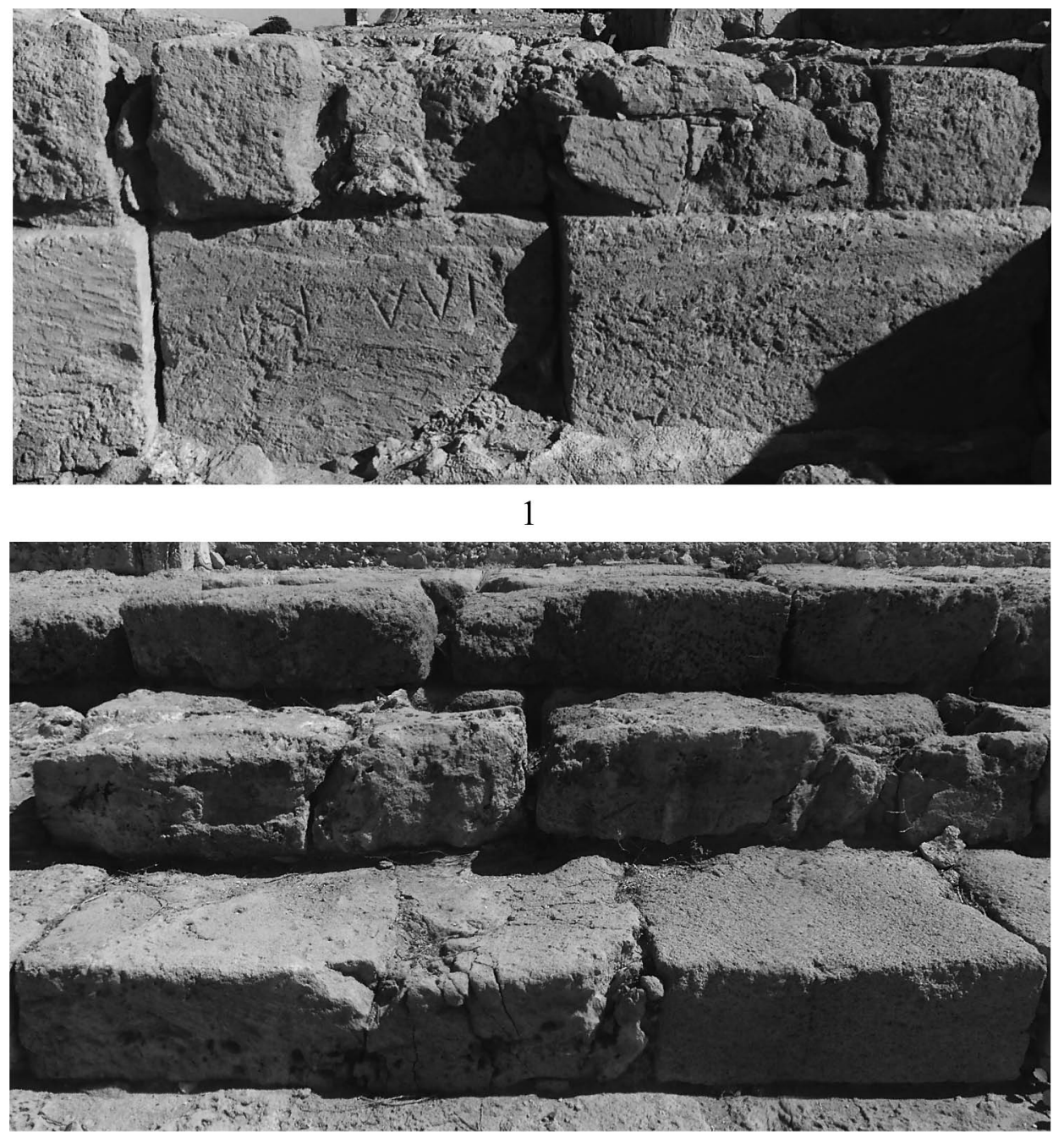

2

P1. 4. 1 - Part of a wall with an inscription from Trench II. Point clouds with overlaid colours. Drawn by P. Ćwiąkała, K. Matwij, W. Matwij; 2 - Part of a stylobate from Trench II. Point clouds with overlaid colours. Drawn by P. Ćwiąkała, K. Matwij, W. Matwij 

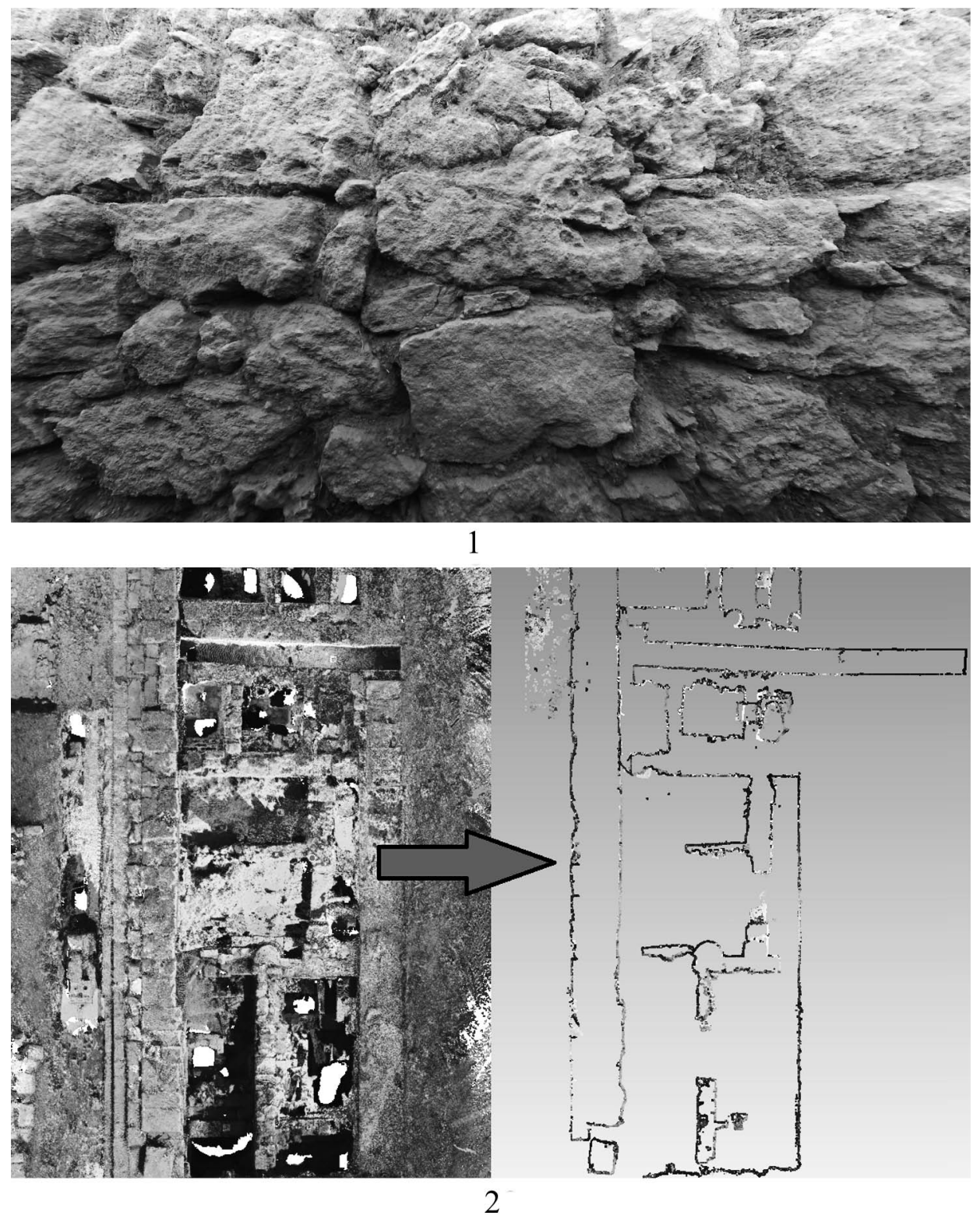

Pl. 5. 1 - Part of a wall from Trench III. Point clouds with overlaid colours. Drawn by P. Ćwiąkała, K. Matwij, W. Matwij; 2 - Example of a cross-section of Trench II. Drawn by P. Ćwiąkała, K. Matwij, W. Matwij 

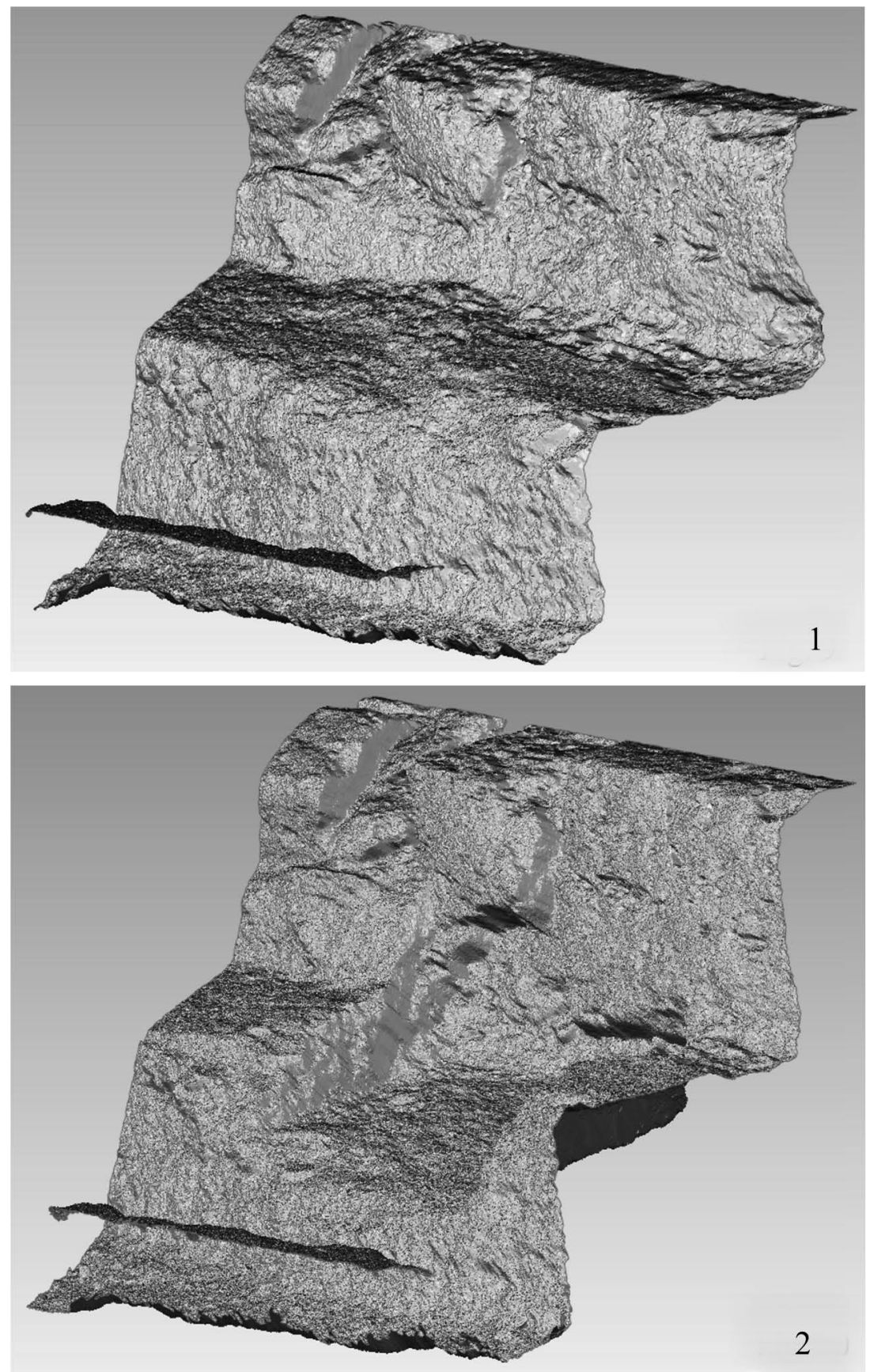

Pl. 6. 1 - TIN for the first stage of exploration in the Trench I section. Drawn by P. Ćwiąkała, K. Matwij, W. Matwij; 2 - TIN for the second stage of exploration in the Trench I section. Drawn by P. Ćwiąkała, K. Matwij, W. Matwij 

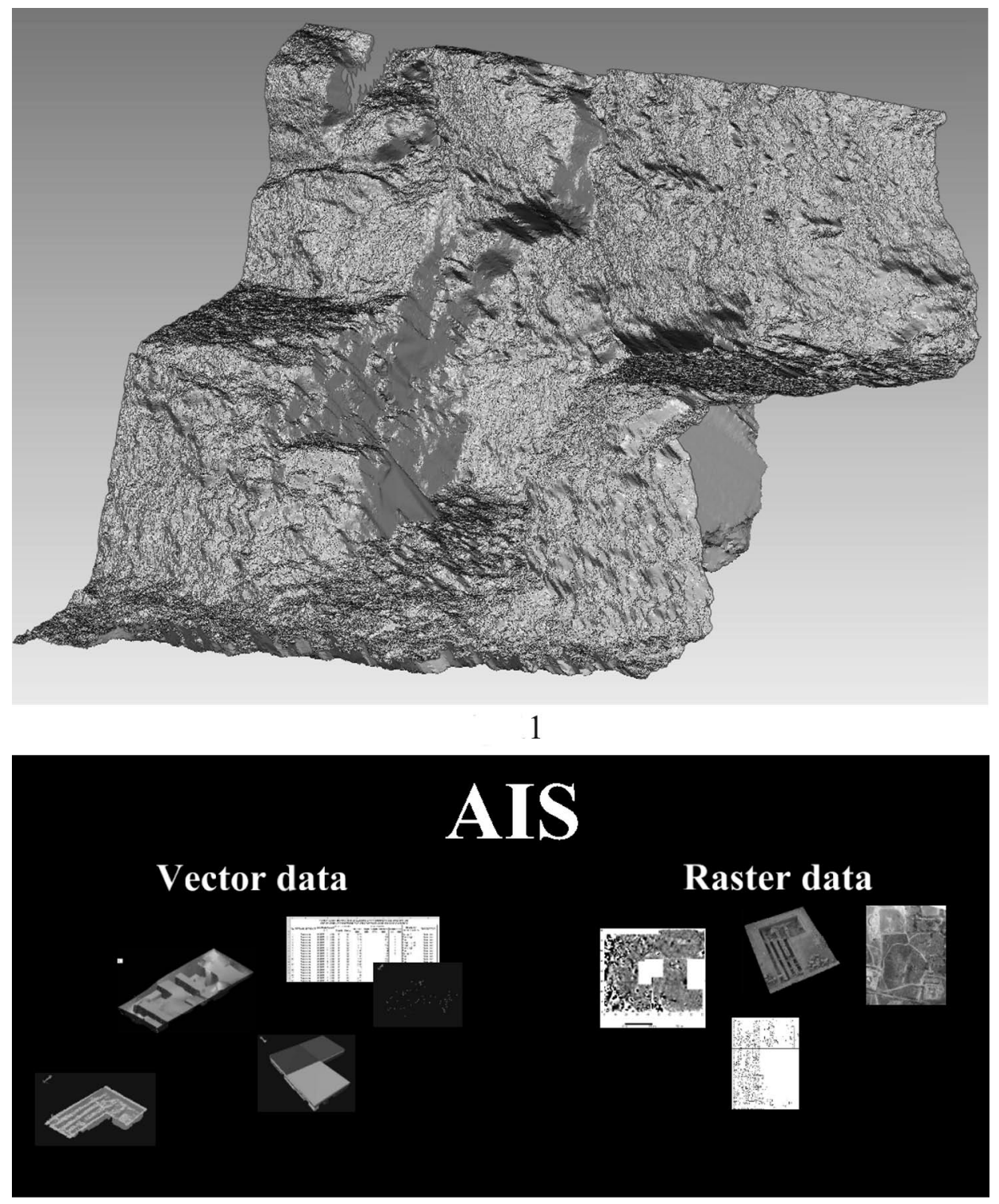

Pl. 7. 1 - TIN for the third stage of exploration in the Trench I section. Drawn by P. Ćwiąkała, K. Matwij, W. Matwij; 2 - Graphical comparison of data collected in the database. Drawn by W. Winiarska 

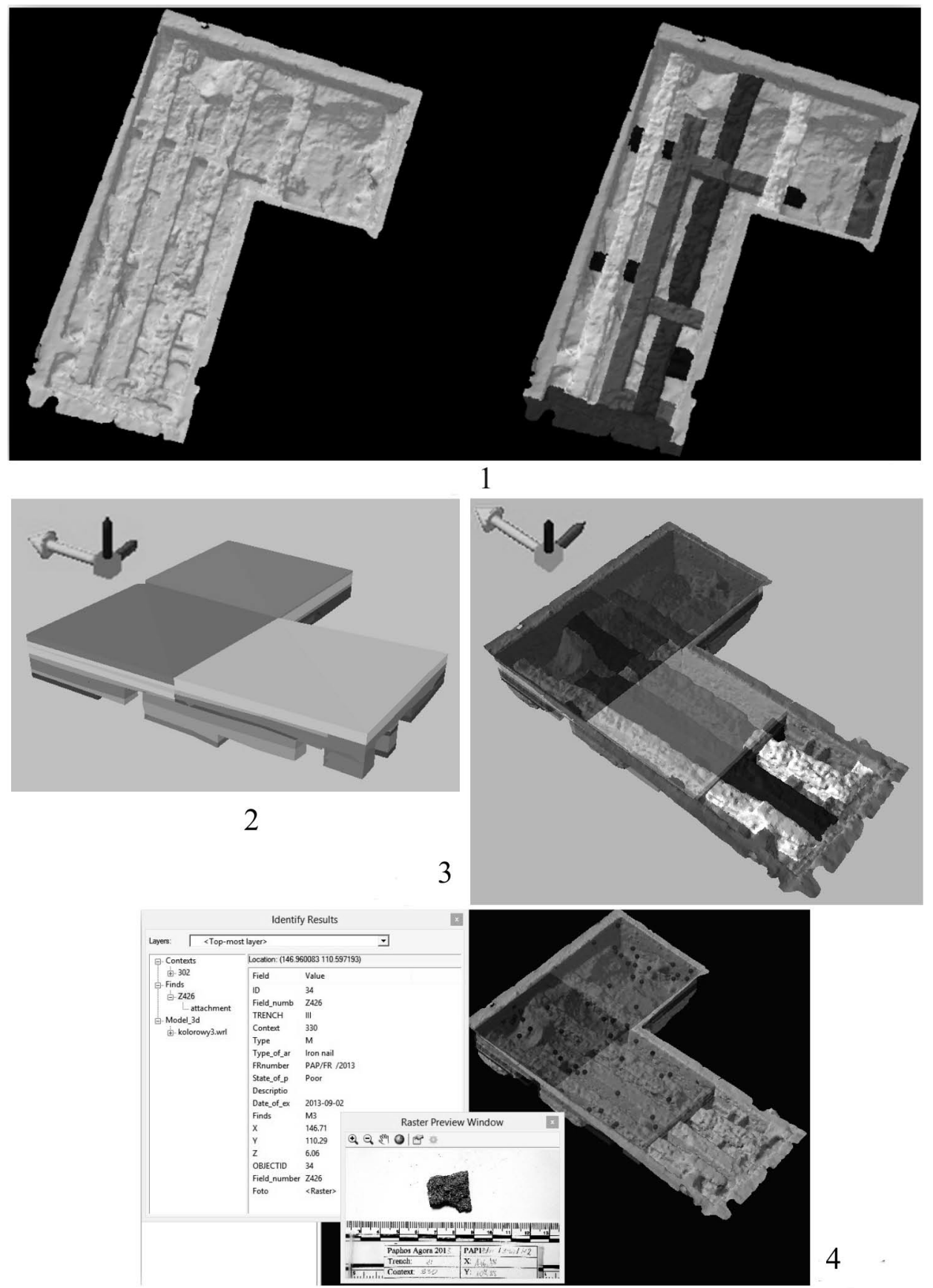

P1. 8. 1 - Model of Trench III before and after isolation of individual structures. Drawn by W. Winiarska; 2 - Stratigraphy restored and drawn in CAD. Drawn by W. Winiarska; 3 - Model of stratigraphy coupled with model from 3D scanning. Drawn by W. Winiarska; 4 - Graphical 3D database of Trench III. Drawn by W. Winiarska 